\title{
Stories of Traditional Magical Healing as Belief Narratives: Between the Supernatural and Secular(ised) Experience ${ }^{1}$
}

\author{
Smiljana Đorđević Belić \\ Senior Research Associate, Institute for Literature and Arts, Serbia
}

\begin{abstract}
This study analyses the distinctive features of stories of magical healing - thematic (meeting of the natural and supernatural as the core of the narrative), structural (stability of motifs, incorporation of other folklore genres - curses, blessings; didactic statements, cumulativity), and ideological (being based on a system of beliefs). In the genre system of folklore, stories of magical healing occupy a liminal space, right at the crossroads of two semantic fields, the demonologically coded and the secular(ised), as the connection with the supernatural is sometimes only latently present. On the one hand, they introduce mythologicaldemonological elements into the everyday, and on the other, they make abstract demonic content concrete by linking it to the plane of experience. Stories told by cunning folk about successful magical healing are an important factor in their social positioning and the verification of magical practice. The circulation of such stories within a community facilitates the creation of a picture of specific practitioners, the domain of their competences, and the effectiveness of the ritual acts. Viewed more broadly, it also creates ideas about the natural and the supernatural, the worldly and the otherworldly, eschatology, morality, and codes of conduct in the broadest sense, even when tradition is rationalised, subjected to doubt, or disagreed with.
\end{abstract}

Keywords: stories of magical healing, charming, folklore genre, demonology, mythology of everyday life

\section{TRADITIONAL MAGICAL HEALING IN CONTEMPORARY SERBIAN CULTURE}

This study is based on the author's many years of experience researching traditional culture (including traditional medicine) in different locations of Serbia. The content has been abstracted from several interviews, but the analysis and conclusions are based on a wider insight into the synchronous state of the tradition of verbal charms.

1 This paper resulted from research undertaken as part of the project Serbian Folklore in Intercultural Code (No. 178011) at the Institute for Literature and Art in Belgrade. The project is supported by the Serbian Ministry of Education, Science and Technological Advancement. 
The ritual practice of verbal charms or incantations is hard to define precisely, considering that it belongs to different layers of traditional culture. Incantation is a part of traditional medicine, a complex and heterogeneous field that also includes traditional phytotherapy, ethnobotany, and ethno-veterinary medicine. The practices that enter the domain of traditional medicine vary according to their aim, including the areas of prevention and traditional diagnosis, as well as the methods related to curing specific ailments (of people and animals), and these are based on the belief in the magical power of words, plants, and movements. Incantation, therefore, is an inextricable part of traditional medicine in the widest sense, and, accordingly, all acts directed at achieving a positive or negative outcome (in any type of simple or elaborate ritual complex), through the directing of reality with the purpose of reshaping it in the desired direction through different means of contact with metaphysical entities, are included under the term magic (Todorova-Pirgova 2003). The variety and complexity of the practice understandably leads to terminological inexactitude in their designation. Serbian folklorist Ljubinko Radenković, who specifically studied incantations, used the term verbal charm as an "aggregate" term for a series of magical practices, defining the verbal text as incantation (basma) and the bearer of the practice as cunning woman (bajalica) (RADENKović 1996). These terminological solutions have mostly been accepted in modern Serbian folklore studies. ${ }^{2}$ The author collects and publishes rituals and texts related to healing and prevention, as well as texts from the domains of love magic and economic magic, etc., in this relatively heterogeneous corpus (RADENKOvIĆ 1982). ${ }^{3}$ Ekaterina Velmezova (Velmezova 2004:17) explains the perplexities in text genre definitions and types of practice by the absence of a developed terminological apparatus with which clear differentiation between functionally diverse small forms of folklore that belong to the group of magical texts could be achieved, and she refers to a particularly ironic remark by Vladimir Kliaus (KuIAus 1998:38) that there are as many opinions as there are researchers. An examination of current Slavic research material indicates that the key problems in defining diverse practices have been registered as follows: the function of rituals in terms of the orientation towards a positive goal or towards inflicting harm; the nature of the metaphysical entity with which contact is established ("pure"/"impure"); whether or not the knowledge is considered taboo; and who the bearer of the practice is (a chosen individual or a wider circle of people) (LeVSKIEvSKAIA 1999:347-350; Todorova-Pirgova 2003; AgaPkina 1999:239). The following analysis will consider charming related to healing practices focused on the prevention and cure of diseases.

\footnotetext{
2 The etic perspective expectedly offers a more complex terminological system. The bearers of magical healing knowledge do not often define themselves with a specific term, and it is not unusual for them to feel the need to distance themselves from negatively tainted titles (for example, pythoness (vračara) ) - creates a connotation with black magic; fortune-teller (gatara/gatalica) - other than predicting the future, gives a connotation of cheating and misusing someone's trust, etc.). On the other hand, some terms are dialectically determined, and thus pythoness (vračara/vračka) in southeastern Serbia is a neutral name for a cunning woman. For more regarding titles for people who practise charming, see RADENKOVIĆ 1996:14-15; for a Slavic context, see LEVSKIEVSKAIA 1999:348.

3 A similar heterogeneity characterises other Slavic corpora (for example, a Russian corpus based on recent fieldwork: ANIKIN (ed.) 1998; AgAPKINA et al. (ed.) 2003, Czech, based on older ethnographic sources: VeLMEZova 2004; etc.).
} 
Accelerated socio-economic changes (especially after the Second World War) have influenced the transformation and disintegration of traditional culture as a relatively stable and more or less closed socio-cultural system. These circumstances have led to a change in the status (in terms of perception and exercise) of traditional magic and charming. Such process has two basic causes. Firstly, the understanding of diseases, their causes and, with that, the concept of their treatment has changed due to the dominance of the conventional medical system. However, it can be shown that, in a system of thought characteristic of traditional culture, traditional and conventional medicine are not entirely mutually exclusive. The second cause of change and the reduced importance of "traditional folk medicine" is the global phenomenon of the development and popularisation of alternative healing methods. Even though the research this study is based on was conducted primarily in rural areas, it is impossible to claim that the opposition of traditional medicine - alternative medical practice today fully corresponds to the opposition of rural — urban, although there is no doubt that the transformations of "traditional folk medicine", including immixture with various alternative forms of healing, is a product of socio-cultural changes, urbanisation being the first and foremost of these. "Traditional folk medicine", however, is not the complete opposite of alternative medical practice. Even though both of them have grown from different traditions and differ in the manner in which a disease is conceptualised and treated, it is not impossible for a person to have a healing repertoire that includes both "traditional folk" practices and those stemming from the post-New Age and esoteric realms. These hybrid repertoires may include individual ways of incorporating different teachings in a system of one's own, traditionally based, developed notions (KIS-HaLAS 2012). Finally, the networks of healing narratives are formed around both "traditional folk medicine" and magical practices, as well as around alternative forms of healing

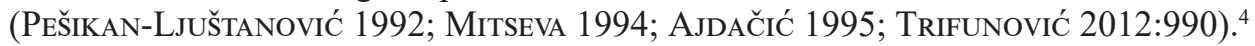

The aftermath of these circumstances are the following: 1. a reduced spectrum of diseases that are conceptualised in a traditional way (and with that, the lack of a need to cure them using traditional, magical means); 2. a narrower repertoire of magical knowledge and verbal charms; 3. the transfer of one part of charming and magical practices into the domain of passive knowledge; 4 . the formation of hybrid repertoires (including traditional folklore knowledge and alternative healing practices); 5. a change in attitude towards taboos regarding magical healing.

The de-tabooing of a practice - especially the text as an element of charming, which was a taboo of the highest degree in traditional culture - can be affected by different factors. Firstly, the weakening of the taboo system can be the consequence of the peculiarity of the specific local ethno-cultural tradition (the tendency to de-taboo is characteristic in eastern Serbia, while research carried out between 2003 and 2005 reveals that, for example, Serbs in Kosovo and Metohija found the text still to be an absolute taboo). Next, attitude towards the text can be individually conditioned, and revealing the

\footnotetext{
${ }_{4}$ The entry into the domain of media discourse, characteristic of alternative medicine in Serbia, especially since the 1990s (the expansion of alternative medicine in the post-socialist period can be found in more detail in TRIFUNOVIĆ 2012:993-994; RADULOVIĆ N. 2018), also partly characterises traditional medicine. Some of my interlocutors have been guests on TV shows; some stories and confession can be found on internet forums, etc.
} 
text to the researcher is at times, it seems, motivated by the desire to preserve traditional knowledge (especially in conversation with interlocutors who are the last bearers of magical practices, with whom the chain of transfer ends ${ }^{5}$ ). Finally, it would appear that some types of charming are especially prone to de-tabooing - for example, the charming of spells (the evil eye). Their transition into the domain of common knowledge was probably motivated by the fact that they were predominantly linked to the protection of children. ${ }^{6}$ Furthermore, it bears mentioning that magic formulas connected to collective rituals directed at the prevention and cure of certain diseases (as well as protection from the elements or natural disasters) are a part of common practice and knowledge, and therefore are not subject to taboo (See ĆIRKOvić 2006:340).

However, in spite of the transformations, reductions, and tendencies towards the "opening up" and "profanation" of magical knowledge described, research reveals that, even at the present moment, it persists partially in the sphere of secret or taboo (or it exists on their borders) while belonging (primarily) to the "consecrated" (in terms of how it is acquired/taught, the taboo system, the status these bearers hold in the community). According to the range of the collective in which they act, contemporary traditional cunning folk, regarded most broadly, can be divided into several groups: 1 . those who rarely practice magic anymore due to lack of need or interest in the collective (their magical knowledge currently lies in the sphere of passivity); 2. those who act within the range of their smaller communities - their neighbourhoods, villages; 3. cunning folk who have patients from various and sometimes very distant places (in stories about their own magical knowledge, but also in how their practice is seen by others, the width of the domain in which they act is highlighted, sometimes even the specificities of the clients - for example, people from the political elite, music stars, and so on). The development of the repertoire of magical knowledge needn't correlate with the position of the cunning folk in the community; for example, some of the interlocutors, people who are famous in relatively wide terms, may practise only one form of magical healing (most often molybdomancy, a practice involving the pouring of molten lead), which, as it will be explained in the following passages, can cover a wide range of the disease and ailment removal spectrum.

\section{TRADITIONAL MAGICAL HEALING IN A FOLKLORISTIC INTERVIEW}

The material that will be cited in these passages was acquired through specific communicative situations - situations of a (partially structured) folkloristic interview.

\footnotetext{
5 In conversations about traditional medicine and charming, a researcher can be seen in different ways by the interlocutor: as someone who is interested in tradition for scientific reasons, as a potential "stealer" of knowledge, or even as a potential patient (more detail in ĐorĐEvić BeLIĆ 2015).

6 Discussing verbal charms in Polesie, Tatiana AGAPKINA (2003) ascertains that almost every married woman knew and practised several rituals in the case of a child or a loved one being sick. In "tougher" cases, "professional" help was sought (this stratification of the domain of competence is also registered in other, non-Slavic European traditions, for example, see STARK 2009).
} 
The context of the semi-institutional dialogue/polylogue, in which the researcher herself was one of the central actors, has undoubtedly had a significant impact on the choice and shape of the content quoted, even though the situation was marked by spontaneous conversation at times. The specificity of the interview was conditioned by the topic itself, which was linked to magic and conjuring - a specific layer of traditional culture. In the previously described socio-cultural frames, which include the destabilisation of the status held by traditional medicine, belief in traditional healing and similarly in magic and conjuring, can also be evaluated as something the community finds to be nonrepresentative, primitive, something which stands apart from the sphere of "official" religion. Therefore, the research of these phenomena demands that the researcher have a certain personal sensibility, field experience, and ethnographic knowledge (ĆrRKović 2006:341; ILIĆ 2007:152-153; ĐORĐEVIĆ 2008:390-391).

Even though each interview presumes a uniquely developed and defined relationship between the researcher and the interlocutor, each interlocutor is a bearer of traditional culture and thereby an authority on it, in whatever type of research happens to be mentioned in this text (whether or not they are a bearer of magical knowledge). On the other hand, the power of the interviewer is reflected in the fact that, however involved $\mathrm{s} / \mathrm{he}$ may be in the research process, $\mathrm{s} / \mathrm{he}$ is in essence leading that process: from planning and conducting the interview, to the interpretation of the data in the scientific text.

\section{STORIES ABOUT MAGICAL HEALING}

\section{The borders of the genre}

Methodology that includes a significant emic perspective has allowed for traditional magical healing practices to be illuminated from the perspectives of the very bearers of the tradition and members of the community in which they function. Consequently, narratives about traditional magical healing practices have been evaluated from anthropological, anthropo-linguistic, folkloristic, and folklore-anthropological perspectives (For example, Hedeşan 2003; 2005; PublichuK - Toporkov 2012; Ilić 2007; ĆIRKović 2006; 2015; ĐorĐEvić 2008; 2011; KIs-Halas 2012). Some collections of recent fieldwork material (in the framework of Slavic folklore studies) also include different narratives concerning magical practices, their bearers, and healing stories, along with the magical texts (Todorova-PIRGOva 2003; Moroz 2012).

Healing stories are stories of one's own or someone else's personal experience, and so the shaping and interpretation of that content is strongly marked by the individuality of the narrator. However, it is important to bear in mind that even personal experience stories ${ }^{7}$

\footnotetext{
7 Different terms are marked differently in literature for this type of narrative ("life story", "life history", "life experience story", "personal narrative", "personal experience narrative", "(auto) biographical narrative", "telling about life"), and their use depends on theoretical-methodological paradigms and the problems on which the specific research focuses.
} 
essentially rest on universally modelled principles. The universality of the layers of personal experience narratives has been established from one angle in socio-linguistic research, and their structure, semantics, and functions have been illuminated from another in folkloristic studies. The foundation of socio-linguistic and anthropo-linguistic musings lies in the research of William Labov (LABOv 1972; LABOv - WALETZKY 1967), who distinguishes six structural parts in personal experience narratives (abstract, orientation, complicating action, evaluation, resolution, coda). And yet these results can only be a starting point for evaluating (auto)biographical narratives such as folklore, and therefore the line of research that focuses on their relationship with the collective and tradition, as well as on other parameters that make it possible for personal experience narratives to be observed within a system of folklore genres (transmission, folklorisation, etc.), is especially significant for this study.

In his "classic" study on the process of the shaping and transmission of memories, Lauri Honko (HoNKo 1964) pointed out the influence of "real" and emotional aspects related to the experience of the situation, which is then shaped in the narrative as a memory, while highlighting that these aspects are not independent of accepted social norms and values. Those norms and values are part of the adopted tradition, and they will also reflect on how narratives are formed, as well as their further transmission. By asking questions regarding social, cognitive, and emotional aspects in the formation of memory, Honko practically anticipated some of the conclusions that were later reached in the psychological and anthropological research of autobiographical memory. Among other things, the tendency of memory to adapt to the moment and context of telling was observed, and it has been noted that through repetition in different communication situations and the increase of the distance in time from the moment the story content is linked to, these narratives "condense" and gain coherence (Ross 1992:175-176). According to cognitive psychologists, the collective consensus "increases the probability that information will be incorporated into individual memory", and collective knowledge and notions are also linked to the transmission process (BAHNA 2015:14).

It has been noted in folkloristic research that some life stories are (spontaneously) shaped in accordance with the structure and semantic fields of some genres of "traditional" folklore, such as fairy tales or legends (BoATRight 1958; ZeITLIN 1980; BošKović Stulli 1988; WiLSON 1991). Sandra Dolby Stahl, who defines oral personal narratives through three parameters (same self of the narrator with the character in the story - Ich-Bericht $;^{8}$ an implied seeking for the truth of the events that are related; the dramatic structure of the event), points out that the connection with the traditional is expressed through the beliefs, ideas, and concepts of the narrator (Dolby STAHL 1989:15). Linda Dégh emphasises that the creation of the narrator only stems from what is possible within the frame of (folkloristic) conventions, which are regulated by the community (DÉGH 1995:72). The relationship between the individual and the collective,

From a narrative perspective, the storyteller's personal "I" cannot be equated with the "I" which has been projected into the narrative, that is, with the actor of the story. The relationship between "storytelling and extra-lingual reality cannot be factual, natural, and by itself understandable, but it is manufactured and therefore problematic. (...) Autobiographical fiction is not only composed of inventing yourself, other people and events, but also of turning them into the object of the telling" (VELČÍć 1989a: 25). Regarding demonological legends connected with this problem, see PoPOVIĆ 2014. 
personal, and social experience is seen as a two-way interaction, and so "the stories told as 'personal experience' are found to be precious data for their natural way of mediating social values" (VeLČIĆ 1989b:81). Even though the contribution of the collective is hard to determine and define exactly, that is to say, "it is difficult to know for sure the moment when collective turns into private and the 'traditional patterns' become creative acts" (VeLČĆ 1989b:85), it is impossible not to take heed of this relationship. Indeed, as Gillian Bennett states, "through an examination of a personal experience story, we can discover what aspects of tradition have remained constant and still shape people's daily expectations and perceptions" (BENNETT 1985:92). Personal experience narratives are characterised by dynamism and contextual conditioning, as they are the product of the synthesis and (re)formulation of experience into a narrative. Seen from this perspective, the key to understanding them is not found in evaluating the relationship of the story with "real" experience (in order to determine its degree of "truthfulness") but rather in the illumination of the rhetorical strategies that ensure narrative coherence and determine the ways in which (narrative) identity is constructed (VeLČIĆ 1989b:84).

The latent link to the sphere of the demonological-mythological, as well as to belief systems in the broadest sense, means that tales of magical healing approach the complex of belief narrative genres. If "legend" is seen as an umbrella term for a series of thematically and structurally differing subgenres (DÉGH 2001), this is all the more so for the term "belief narrative" (especially bearing in mind the synthetic principle as the base of the concept). Considering the range of the previously noted term, Ülo Valk suggests that it includes a series of diverse genres, from myths and legends to urban legends, rumours, oral histories, and all other types of narratives which are experienced as true stories, and which participate in the transmission and reproduction of knowledge about both the supernatural and mundane dimensions of the world (VALK 2016:27). ${ }^{9}$

The analysis of healing stories as a standalone subgenre imposes the need to view a corpus of relatively heterogeneous examples, narratives shaped by different positions (the perspectives of the cunning man/woman, the perspective of the patient, the mediated experience of another ${ }^{10}$ ). Understandably, the full range of material gathered (interview transcripts), with its extensive spectrum of possible realisations of magical healing stories, cannot be displayed here in full. ${ }^{11}$ Therefore, the examples chosen have been established to be good paradigms for illustrating the characteristics of the narratives on which this discussion focuses (the structure, semantics, role in forming the concept of

9 Even though stories of magical healing are shaped both as memorates and as fabulates, I regard them as a unique corpus, following Linda Dégh on the relativity of the boundaries between them and the possibility for both forms to be viewed as legend (for a detailed analysis of understanding a memorate in folkloristic studies, see DÉGH 2001:58-79). In her study on legends, the author considered the logic of the relationship between magical healing ritual and "healing legend", among other things (ibid:424-425).

10 According to these parameters (i.e., the narrative perspective), healing stories (about unconventional medicine) are classified in a study by Vesna TrIFUNOVIĆ (2012).

11 It should be added that, in the framework of traditional culture, magical healing stories can be linked to cult locations, not only charming: churches and church ruins, monasteries, cult crosses, springs that are believed to have healing waters, etc. From the perspective of cultural history, healing stories have a parallel with stories of Jesus Christ's miracles, the medieval life stories on saints (PEŠIKANLJUŠTANOVIĆ 1992), and the motif is transferred into modern literature as well. 
the supernatural, creating consciousness and knowledge about the bearers of traditional practices and network relations that are formed between them, reflecting the traditional collective concepts in the formation and functioning of stories).

\section{Narrative and belief-meeting the supernatural and the positions of the actors}

Stories of magical healing essentially rest on a complex of beliefs which shape the concept of worldly and otherworldly realities and which are included in the system of traditional culture and the conceptualisation of illness. Belief is defined as a "separate, often folkloric phenomenon that exists as a shared, culturally learned knowledge that induces people in the group to behave and act in a certain way" (DÉGH 2001:311), and it also represents the ideological basis of legend (Ibid). The supernatural is a world that belongs to demonic beings, some of whom are the demons of diseases. Meeting demonic beings in demonologicalmythological legends forms the axis of a narrative and the result of the meeting, most broadly speaking, depends on knowing the code of conduct that operates in these contact situations. The result can be fatal (if an individual does not respect a code or takes no heed of it), or positively resolved for the human (if the system of the desired characteristic prophylactic actions is respected). In stories of magical healing, contact with the supernatural is twofold: the patient is exposed to contact with the otherworldly (this is sometimes implicitly understood, other times performed in the patient's ignorance), and that contact is the cause of the ailments. The second meeting with the otherworldly is created in the very act of charming. This "opening up" of the boundary between two worlds is especially linked to saying verbal charms - "traditional verbal forms intended by their effect on the supernatural to bring about change in the world in which we live" (ROPER 2004:8).

Disease appears as a result of the influence of a demonic entity or, conditionally speaking, human acts (bewitchment, black magic, and so on), but these human acts include a connection with the magical-demonic plane. The concepts of different forms of diseases are made concrete through interpreting the cause of the illness, and the illnesses themselves (the demons of illnesses as well) are conceptualised in a specific way through the texts of traditional charming. Without delving into all the complexities of the problem mentioned, I would draw the reader's attention to the fact that the illness demons may have anthropomorphic or zoomorphic characteristics, but they can also be imagined in a most undetermined way. The healer aims to banish the illness from the body in the charming ritual (and return it to the supernatural realm or to whoever sent it), and thus the basic forms of speaking to illnesses in verbal charms are pleas, orders, and threats (USACHEVA 2000:58).

These two forms of contact with the supernatural differ on several levels: the first is involuntary, dangerous, with negative consequences; the second is desired, initiated by the practitioner of magic. The core difference is seen on the plane of the nature and position of the actors, as the healer, who is in possession of specific magical knowledge, finds himself in a liminal sphere (especially in a ritualistic situation). The position of the healer is a position of one consecrated, one who is, like a bridge, initiating and making possible communication between the natural and the supernatural, the worldly and the otherworldly, and whose specific knowledge allows for the control and direction of the outcome of the meeting of two worlds. 
A detailed description of the ritual is most often absent from stories of magical healing (ĆIRKović 2015:217-218). This can be explained as respect for the system of taboo in the narratives shaped by the cunning folk, but also by a partial redundancy of this kind of information for the semantics of the story, as the accent is shifted from the process itself to its positive outcome. Similarly, the ritual description is somewhat reduced in stories shaped by the perspective of the patients (or a third party sharing someone else's experience). Apart from it being content that doesn't play a key role in the development of the story, the perspective of the patient is narrowed and reduced to "visible" segments of the ritual (most often fragments of the item and action code).

\section{Structure of the story}

The review of a larger corpus of magical healing stories points to it having been shaped, up to a point, in accordance with a certain pattern, rather than being entirely spontaneous and free. The "ideal model" of such narratives would be formed from the following motifs: 1 . becoming ill (the cause of which may or may not be explained, and might be revealed later in the narration, often by the healer) - a description of the symptoms, psychological and physical states of the patient, and so on; 2. going to a doctor - conventional medicine proves to be powerless (in some narratives, there is even the motif of the doctor sending the patient to the cunning folk); 3.the patient goes to the healer; 4. a description of the magical practice that is used to diagnose and/or treat the illness (and the patients often get instructions about further necessary ritual practices they can do on their own - for example, washing their face with water used during the charming, throwing objects used in the ritual behind them at the appropriate time and place, sometimes while also reciting an accompanying verbal charm, etc.); 5 . the effectiveness of the healing - a description of the psychological and physical condition of the patient that is in contrast with the condition that was previously characterised by illness; 6 . the motif of gratefulness on the part of the one healed; 7. final formulae that function as discourse markers (summary conclusions on the effectiveness of the magical practice used, the theme of the link between the cunning folk and the metaphysical level, expressing attitudes towards traditional medicine and magic in general as well as supernatural reality, etc.).

The introduction, combination, alignment, and development of motifs depend on individual storytelling inclinations and intentions. Therefore, the development of stories about magical healing varies from highly developed narratives that include a series of details, from comments, and evaluations (see especially in example [4]), to greatly reduced forms, narrowed down to the nucleus of the narrative. In spontaneous narration (which can be developed in a folkloristic interview up to a point), it is not uncommon to have a web of developed stories and narrowed down reminiscences that have the potential to grow into extensive narrative forms.

The following example, which contains two associated and linked stories about magical healing, is an adequate illustration of the incorporation of nearly all of the elements described in the "ideal model". It was recorded in 2007 in an interview with the cunning woman Ivanka, who lives in Omoljica near Pančevo (southern Banat) and who is a practitioner of several healing practices (settling the stomach, setting bones), as well as 
of the dominant practice of molybdomancy. ${ }^{12}$ The interlocutor took on the role of absolute authority, and this positioning must have been conditioned by a number of factors: as a successful healer, she was known far beyond her community, communicating with a large number of patients from different places was part of her everyday routine, she had even participated in several TV shows. Furthermore, she perceived the researchers not only as people who were interested in her for professional reasons, but as potential patients.

[1]

"The one made it happen here, the wedding I mean, she married her younger son off, and the older one has two children. And now the youngest one, Jelena, the trumpet players came, you know who the trumpeters are, they came into the tent. And as she saw the trumpeters, as they started playing, she screamed and stuttered. And that's it, she stutters, and nothing, stutter, stutter, she can't, she can't speak! And now no one told me, so how could I have known that the child was frightened, I wasn't there with her to know. She calls me, Dragica does, and says: - Come on, please, do the lead pouring for my Jelena! - What's the matter with her now, I said. - I know I did it recently. - Come on, she says, do the ritual. - Fuck, I pour the first lead for her head. [I see] a gun is pointed at the child. - What is this, I said, what are these rifles, guns, what's wrong with your child, for God's sake?! - And she had taken her to a speech therapist. The speech therapist said, he said: - We can't do anything, only a woman can get rid of it, he says. - Well, I say, trumpets! - How do you know, she says, about the trumpets, she says. - I said: - The trumpets scared her, have no fear, she will speak again, you don't need a speech therapist anymore. - And nothing, I just did the ritual three times and the child never stuttered again. She took her to a speech therapist, the speech therapist said: - So, why did you bring her, he says. - Well, you said so. - Well, what did you do to the child? The child, he says, doesn't stutter anymore?! - Well, a woman did a lead ritual. - The child, he says, doesn't stutter anymore? - Well, she says, a woman did a lead ritual. - Didn't I, he says, tell you that the women are stronger than us... I did a lead ritual and healed the child, and he couldn't, and she'd taken her there five times and nothing! When she takes the child, it's back to square one. The child stutters and can't do anything and then [she imitates a stuttering child] I did a lead ritual three times and the job is done for the child." 13

The next example has been taken from the transcript of an interview with the cunning woman Koviljka (born 1926), from the village Rečka (eastern Serbia), that was conducted

12 Strava ('fear') as a type of illness manifests itself with a wide variety of symptoms (crying, sleeplessness, anxiety). In traditional culture, the appearance of these symptoms is linked to a sudden intense feeling of fear and a stressful event. The molybdomancy ritual is focused on identifying the cause of the symptoms (the healer interprets the symbolism of the shapes which are formed when molten lead is poured into water, practically reconstructing the event that caused the problem). Then the illness (strava as a negative content) is "drawn out" from the body of the patient and "passed on" to ritual objects - the lead and water used in the ritual. The illness is sent to the "other side" by throwing the ritual objects to symbolically marked places that are linked to the supernatural (water, a dump, etc.).

13 All the transcripts in this study are partially stylised and reduced for the needs of translation. The symbol (...) marks where parts of conversation have been omitted, and also in the angular brackets we have remarks on the paralinguistic elements, as well as data and explanations necessary for understanding the text. 
in 2006. Koviljka's traditional magical knowledge is extremely rich and encompasses the healing of many diseases: pokostica, poganac, metaljka, očibolj, crveni vetar, ${ }^{14}$ consequences arising from the actions of the noćnici and babice demonic beings, ${ }^{15}$ after a bewitchment has been cast. Her healing abilities were well known in her own and in surrounding villages, as well as in the town of Negotin towards which this area gravitates. Although at the time I spoke to her Koviljka was the last bearer of magical healing knowledge in the village, she had been hoping her son would adopt the knowledge. Even though her charming narrative was marked by comments that revealed "cracks" in the status of traditional medicine in modern conditions, Koviljka was completely assured of the effectiveness of her own practice, and she illustrated this effectiveness with a series of more or less developed stories about successful healings. Let us observe the structuring of a part of this conversation:

[2]

K: "Zorka's Borka was sitting in Belgrade for a month. Getting injections... Her daughter, Vesna, told Borka, and she told me about it... And she sat for a month in the hospital, getting injections, she says, the fire wouldn't die down, it was getting bigger and the doctors said, they said: - We know, he says, where there are babice, and we don't know how to do it. - And she, and they let her out of the hospital, and she comes home, and Borka brought her to me. She says: - Koviljka, you know why I've come? (...) - I know. - Whoever comes to my door isn't coming because of something good, always because of some trouble... Yes. What is it? - And she says: - Can you come over, she says, with us, we came by car, she says, we're going to go. - Alright, I said, let me just close my door and, I says, I'm coming. - Now I asked her. - Her head, she says, gets as red as a rose. - Now we will see, I said, if it is that, I said, and if it's not, I said, then it's not. - And we get there, and the girl is lying on the bed and she sits up. - Good evening, girlie, I said. - She says: - Good evening, granny. - How're things? - Not, she says, not really good. -How, I says, do you feel generally? - She says: - The fire doesn't stop. Alright, never mind, now I will tell them what to bring me, and I will charm and tell you what to pour in that water, and no cattle should pass by, nor you either, the wind blowing overnight, and mice and cats will pass by and something, and they will carry it away so it won't attack you, I said. - And me..."

The neighbour: "When someone else steps on it, it will pass onto him."

K: "Well, that's right, that's it... And I left afterwards, and when it happened, I later asked Borka, she said: - May you be alive and well, she says, granny Koviljka, and healthy, now my Vesna is alright, she said. I said: - May she be well, everyone has bragged because of my hand... and there, that's it..."

14 The names and symptoms of diseases in traditional culture most often do not match diseases registered by conventional medicine. Thus it is important to provide a short description of these diseases: pokostica manifests as stabbing pains in some part of the body; poganac is a subdermal illness; metaljka is inflammation of the eye; crveni vetar ('red wind') is a skin disease which manifests in redness and inflammation; the symptoms of ocibolj ('eye pain') are red and watering eyes (RADENKOVIC 1982:397, 398, 400, 410).

15 Noćnici - night demons that usually attack children; babice - demonic beings that threaten a woman giving birth and the newborn within a period of 40 days postpartum. 
K: "I know so much, so much, as they say, both from poganac, and from that pokostica... That pokostica, it hurts so much, and no peace, they give you no peace... And eye pain, and all sorts... Who knows as well as I know, as they say, how to charm... People have gone to the doctor and got no help, so when they come to me, I charm, and then it helps them after... And that Dragica, whom they call Držna, she died... And she said: - I went, Koviljka, she says, to doctors, she says, I spent so much money, she says, and it didn't help me. And she came to me three times, I charmed, and it helped. I don't ask for money, I say: - Lord God help me, and that's that. I did good things for everybody."

The first story, introduced through a discussion of child delivery demons (babice), initially functions as an illustration and explanation of how they act, developing then into an extensive narrative on magical healing that includes a series of details (symptoms of the disease, the visit of the sick person's mother to Koviljka in order to seek help, the cunning woman going to see the sick person, and an abridged description of the ritual). The narrative in first person is supplemented by the introduction of the voice of the doctor, the dialogue segments, introducing the voice of the reasoner (the sick person's mother) who brings the story to its conclusion - expressing gratitude to the cunning woman for the successful healing, which is followed up by a comment from the healer about the effectiveness of her own practice. In the next segment of the conversation, the emphasis is on the scope of her repertoire of magical knowledge, using association to introduce healing stories. Through generalisation, a certain "general model" of behaviour is formed ("And people went to doctors but it didn't help, then when they come see me, I charm, and then it helps them..." [2]), which then becomes concrete through the abridged story of healing a specific person.

The cunning folk's perspective: the rhetoric of truth as part of the "rhetoric of competence"

"Belief in truthfulness" has been taken as one of the fundamental characteristics when defining legend as a genre (See review research in: BošKović-Sulli 1975; DÉGH 2001:23-97; OrING 2008:128-129; MiLOŠEVIĆ-ĐorĐEVIĆ 2006:174-176; SAMARDŽIJA 2011:273). Still, by taking into consideration the dialectical nature of folklore, the premise of believing in the truthfulness of the tale that is told is relativised. As Linda Dégh points out: "We identified believers, half-believers, hesitants, doubters, sceptics, and nonbelievers (...) producing positive and negative legends as well as anti-legends. (...) It is not the positive declaration of belief that makes a legend a legend but rather the debate of participants considering the legend's believability" (DÉGH 2001:311). In Elliott Oring's research, shifting from the ontological plane to the level of presenting events has led to the formulation of the concept of "the rhetoric of truth". ${ }^{16}$ This theoretician does not limit himself only to narrative strategies (the narrator's position, storytelling in the first and

16 Narrative strategies related to "truthfulness" in demonological legends have been discussed in the last few years in the framework of Serbian and Croatian folklore studies (RUDAN 2006; Popović 2014), including the attitude and role of the researcher in the process of "negotiating truth" (ĐorĐEvić Belić 2013:237-239); it points to a problematic etic perspective in defining the genre of legend (DeLIĆ 2018). 
third person, the place of the narrator in the chain of knowledge transmission, introducing "foreign" voices through direct speech, metatextual comments, etc.), nor to paralinguistic elements, but rather he points out the importance of the communicative context in a broader sense, highlighting the significance of fitting the point, meaning, and message of the story into the ethical-axiological code of the community, into collective ideas and knowledge.

Let us observe how the rhetoric of truth is activated and functions in the examples listed. Personal witness - a form of memorate (i.e., a fabulato-memorate in segments that rest on the mediation of another's experience) - means that the chain of knowledge transmission is shortened to the minimum. The story is told by the healer, the main actor (and in some segments the perspective of the patient is taken, describing the experience of becoming ill, the symptoms and ailments, going to a doctor, introducing his answers through direct speech), which then significantly contributes to the illusion of the truthfulness of the "(auto)biographical fiction" (VELČIĆ 1989a:25). The strategies by which the idea of the other actors are formed are part of the mechanism of the rhetoric of truth. The listing of concrete names and other data ${ }^{17}$ can also be interpreted as a tendency for the actors to be presented as witnesses, those who can confirm the validity of the story.

Since the mentioned motif of a powerless doctor is a relatively long-standing and stable element in narratives of magical healing, its role in the rhetorical plane is often quite clearly highlighted. Introducing the voice of the doctor has, it seems, multiple functions. With it, from one perspective, one stresses the difference between the domains of effectiveness when it comes to traditional and conventional medicine, which shatters the idea of opposition and "rivalry" between the two types of healing: ("And she sat for a month in the hospital, getting injections, she says, the fire wouldn't die down, it was getting bigger and the doctors said, they said: - We know, he says, where there are babice, and we don't know how to do it..." [2]; “... and she had taken her to a speech therapist. The speech therapist said, he said: - We can't do anything, only a woman can get rid of it, he says..." [1]). Furthermore, the validation of traditional medicine and the concrete bearer of magical practice from the point of view of the doctor is a way of introducing the voice of authority. Apart from the doctor being the representative of conventional medicine, the roles of external authority can be taken on by representatives of different institutions - symbols of social power: for example, policemen and priests ([1]), professors ([4]), music stars (See another example in TRIFUNOVIC 2012:987). This "other voice" is often introduced into the narrative as a third person in the role of reasoner ("Didn't I, he says, tell you that the women are stronger than us..." [1]), and this role can be given to the cured person, or the one who initiated the healing ("May you be alive and well, she says, granny Koviljka, and healthy, now my Vesna is alright, she said..." [2]). ${ }^{18}$

17 For example, explaining about the family relationships between the actors, even though the researcher doesn't know the people in question, their social status, where the patient comes from, etc.; these aspects of the narrative of cunning folk are analysed in detail by ĆIRKOvIĆ 2015:215-228.

18 Analysing the quotation of dialogue in stories of magical healing, as well as drawing attention to the role of actions that give dynamics to narration and achieve credibility, linguist Svetlana ĆIRKović (2015:219) points out that this is a "speech performance". Indeed, by taking on another's words, the narrator temporarily "plays" the role of another person. The same author sums up research on reported speech, which shows that reported speech quotes can be introduced with reporting verbs, the names of the interlocutors, but also through non-linguistic strategies, such as a shift in the tone of voice, gesticulation, facial expression, pauses, etc. (ibid:208). 
The strategies of the rhetoric of truth are also activated through the way the action is led, depending on the narrator's capabilities. In that sense, the dialogue segments mentioned can also have a dramatic and expressive function.

The distinctive features of the stories told from the perspective of the cunning folk are represented by sentence-shaped (and sometimes didactically directed) statements that come up within the frame of the narrative in most cases (especially in the final position, or the medial, in the case of larger narrative macro-blocks). Paremiological genres, such as oaths and blessings, can be found in the same position. These verbal structures can be defined as final formulae that are emblematic of the successfulness of one's practice, one's relationship to the metaphysical entity, one's position within the community, one's relationship with religion, etc. ("May you be alive and well, she says, granny Koviljka, and healthy, now my Vesna is alright, she said. (...) said: - May she be well, everyone has bragged because of my hand... And there, that's it... [2]; I don't ask for money, I say: - Lord God help me, and that's that. I did good things for everybody..." [2]). The appearance of nearly identical constructions in the narratives noted by the same interlocutor profiles them into stable formulative elements of a concrete idiolect (ĐorĐEVIĆ 2011).

Seen from the perspective of the theory of personal experience narrative, segments of the rhetoric of truth would mostly be included in the evaluative plane of the narrative, which is especially significant for social interaction. With that, these elements may be part of an implicit or explicit external evaluation.

The embedding of the story, its meanings and connotations in an ethical-axiological code and system of beliefs and ideas of the community is implicitly present, but it is specifically explained in example [2]. Indeed, the healer's neighbours were also present during the conversation, and one of them would occasionally join the conversation as a commentator, feeling the need to clarify potentially unknown facts to the researcher. In this way, actually, she revealed her knowledge of the regulations related to the system of beliefs on which ritual healing rests (for example, explaining that water used in the ritual should be emptied somewhere where nobody walks, so that a person doesn't unknowingly take onto him/herself the negative contents condensed into the water by walking on it). On the other hand, some of the interlocutors didn't feel the need for further explanations, probably presuming that the researcher possessed similar cultural experience.

Analogous to the concept of the rhetoric of truth, it is possible to talk of the "rhetoric of competence". ${ }^{19}$ This would include elements of the narrative of the bearer of magical practices in which the mode of acquisition and the repertoire of magical knowledge are thematised, the concepts of paying/rewarding/gifting, the motivation for healing. In a nutshell, the rhetoric of competence would represent an important factor in the formation of a "professional" layer of the narrative identity. Stories of successful healings would function as par excellence elements of the rhetoric of competence, as they represent the central modus of the narrative verification of one's own practice.

19 Formulating and further developing the concept of the "rhetoric of competence" seems promising, since the term could function as part of an analytic mechanism in the consideration of the narratives of different bearers of specific knowledge (different traditional skills, artistic practices, etc.). 


\section{The patient's perspective: the spectrum of points}

Stories about magical healing are understandably also passed on by those who have experienced it. Such stories are often received in a folkloristic interview as a form of individualisation and concretisation of a practice that functions in a community, like an episode in a broader life story [4], or as an illustration of demonic content that had previously been discussed, as was the case in the example of a conversation with the cunning woman Dara from the village Tamnič (eastern Serbia):

[3]

D: “For fairies... It was said, and once I, I didn't see it, but I was pruning in the vineyard. (...) It was springtime, and such a strong wind was blowing as if it was going to thunder, under one walnut, and so it bent around the trees, loudly. That's what I heard, they say, it's fairies playing. And I never saw them. I just heard the wind..."

(...)

S: "Can that be dangerous?"

D: "Yes, dangerous. When I was going with my daughter, I was, I was with little children in the field... And off I went, I went from that vineyard there... And the whirlwind hit me. And the child was behind me, it hit onto me. And as I reached the house, I was so tense, tense and itching everywhere... And I was there at some woman's, she charmed for it, and it passed... And that was, it was an impure wind..."20

The following example is interesting in several ways. It is part of a conversation with an interlocutor who was born in 1922 (in Minićevo, southeastern Serbia), that took place in the presence of her nearly entire family (daughters and granddaughters) and a neighbour, so the atmosphere was almost that of a natural, everyday sort of conversation, becoming more spontaneous as it went on. Because the people taking part in the conversation were encouraging the interlocutor and reminding her of things to mention, I as a researcher was somewhat pushed into the background, thus becoming more of a listener rather than someone asking for concrete information. The housemates' interventions revealed content that was familiar to them, as these were elements of a family folklore. The interlocutor introduced the following narrative into an autobiographical story, linking it to memories of a wedding:

[4]

"And the wedding had been a week before. When Kole [the interlocutor's husband] left and returned, that woman who made... [talks to the neighbour] Maybe you know Dripalka, Stevka, Jevrosima's granddaughter. She's a hermit, all alone, God gave up on her, she even ruined another house... (...) And Kole comes: - Oh, he says, what a headache I've got. - And I say: - Well, why have you got a headache when nothing was wrong with you? (...) And I went and called his grandfather, and mother: - Kole is not well. - Ohhh! - And right away grandfather Žika, grandfather Žika was a minister in Belgrade, they gave him a revolver in the Parliament

20 According to the findings of Anna Plotnikova (2004:204-206), a link between fairies and a howling wind is characteristic of peripheral zones of the south Slavic areas (south, central, and western Bulgaria, Macedonia, southeastern Serbia, western Croatia, and Slovenia). 
in Belgrade. Grandfather Žika, he was the first politician man... He goes: - So, child, when you came back, did you see anything? - Yes, granddad, he said, Stevka, he said, Dripalka, she went to get me, he said, into, he said, the cabin. - Oh, he said, motherfucker... Never mind. Then grandfather Žika, as Kole started to spit out blood, grandfather Žika got on a horse. And it had started snowing, it was St. Sava's day. And he brought a doctor here. And the doctor says: - It's nothing, it's a heavy cold, it will pass... - One woman came and the doctor left, he gave some medicine, but Kole didn't want to take it. So that woman came, grandma Laće: - Listen, she said, don't stress, it is better to go to that Vitko, he's a cunning man... Don't stress yourselves, don't stress the children... - And they really were, children born to my aunt, my father's sister, and off they went with grandfather Žika to that cunning man and that aunt, too. And he [the cunning man] right away said: - Hey, son, let me tell you, I did, he said, something really stupid. You're very lucky you came to me, otherwise, he said, you would have lost your children. - Grandfather Žika, begins to cry, my father begins to cry ... (...) And that cunning man is my father's uncle: - Uncle, anyway, he said, you can save the children. - And everyone was crying. (...) He says: - Grandfather Žika, don't cry, God has sent you to me, he says, that woman who told you about me, I will fix everything, and this money I have taken [to hurt the interlocutor and her husband], I will take to the church. These cursed coins, I don't need them. - She gave great money. And they say: - Fear not, he says. There is, he says, a better doctor than me. I will, he says, I will revive the children a little, the children have fallen, he says. Here, your grandson is spitting up blood. (...) Kole is splitting up blood. There's blood from his nose, coming out of his mouth, and I know nothing, the bride. One is lying in one bed, the other in another bed. (...) - Just you wash his face. And lift him up and go to Knjazevac to my sister Leposava. She will, he says, save the children, don’t you worry... (...) And grandfather Žika put grandma Ljubica in a tumbrel and they went up to Leposava. When she saw that granny, and grandma Ljubica was howling, howling at the top of her lungs. - Fear not, sister, don't cry. Thank you to the ones who came with you. I will now, she says, for the children... I will charm here, and the children will be better. (...) Kole gave the signal, and from the window you could hear music playing. And nothing, he came back, and then that grandmother Leposava said: - Go, and come, she says, tomorrow. - She [Leposava] was speaking with the fairies. (...) And Kole opened his eyes a bit, and my legs and arms felt paralysed. (...) And then grandfather Žika brought the cunning woman to us. And she said to grandmother Ljubica: - Put out a burner, she says, sister, and light a candle and I'll be there, she says, to call on, she says, what I heal with. And she conversed and sang, with the fairies, with the angels, with Jesus Christ and all, and he said... You see, the strange thing is how we remained alive... And she said, when she came to her senses: - Eh, Ljubo - said the cunning woman... And she spoke to grandfather Žika: - Eh, brother, off you go to find lead, half a kilo of lead, so I can heal the children, and you will see. And you mustn't do any evil to anyone. And you will see who it is... And she, that lead, then she washed us, you see, and we sat on the bed. But we didn't know. She melted that lead. She said: - Children, the picture [drawn on the lead] Stevka Dripalka. Hair back, scarf smoothed, breasts this big, feet all bare. Here she is. - As if Stevka was drawn on that lead. - Take this lead, go to a crossroads, dig a hole, dig a hole big enough that a farmyard animal can fit in it, and put this lead there. And this candle I had at my side. - And grandfather Žika went to the crossroads, and dug a hole and put that lead in the middle of the road. And nothing happened, everything went. And he came... And now, the cunning woman wanted us to go to her so she could heal us like she knew how. They put me and Kole in a car... We ate nothing, we lived off God, just some wine in a glass this small. And we went to the cunning woman and we sat 
there for ten days. For ten days we sat at the cunning woman's as newlyweds, we didn't know anything, we didn't know we were newlyweds, or if we were anything... (...) She healed, she heals, that cunning woman... She even went to Belgrade to heal, she healed professors... (...) Eh, I'll tell you about that after, God punished her afterwards because she wouldn't heal this one child ... (...) When it was three o'clock in the morning, Kole woke me. He went first, so she [the cunning woman] bathed him, with all those herbs and they got stuck on him so you couldn't get it off. And everything was clean and she ordered everyone around, grandmother Ljubica prepared shirts and underwear and everything. And afterwards I, I was after, I went to get him. She bathed us for ten days. She had a weekend cottage there, a house, and water down there. (...) She was, she was God's cunning woman. (...) And one day we started, she gave us, we drank this much wine with a stone spoon... (...) And that wine, it had sat for forty days in a church, in St. Lazar's, do you know where St. Lazar's is? Up there by Rogošta, St. Lazar's, the little church, by the road... It's a big church now, we went there for St. Lazar's day, Kole and I... (...) And so we sat for ten days. And afterwards we went to St. Lazar's church on foot. We didn't even feel it. Maybe we took a drive there, I don't know. Grandma sat up front, we were behind her. Off we went, Kole and I, we didn't feel any discomfort at all. (...) Now, there was an older priest, and I can hear it all [in my head] even to this very day... He put up his hand like this and lifted a cross. I kissed the cross, I kissed his hand. (...) And we took, we placed money on the icon like that, on St. Lazar... And we came back, and after that we sat there another four days. And after that grandfather Žika came. And for two months we didn't go outside. Not until we had recovered a bit, for people to see us..."

This incredibly elaborate story offers a detailed description of a complex system of magical healing, where the interlocutor basically follows a chronological principle for the series of events. The patients (the interlocutor and her husband) are victims of the workings of black magic. We first discover this as being a problem through a brief comment about the husband of the interlocutor meeting a woman who "has done" them ('has harmed' them), which brings the first signs of illness (a headache), for it later to be revealed through the words of the cunning man Vitko that this person paid specifically to work magic geared towards causing harm. The initiator of the healing is firstly the husband's grandfather, who is presented as the central authority figure in the family, with additional highlighting of his social status (he was a minister), and then the advice to go to cunning folk came from an acquaintance who happened to drop by for a visit.

The magical healing that the interlocutor and her husband underwent right after their wedding (newlyweds were particularly susceptible to magical influences) presents a long and complex process: after consulting the doctor, the family goes to the healer Vitko upon the advice of an acquaintance, who ascertains the problem but, seeing as he's not competent enough, he simply relieves their symptoms and sends the patients to another person - his sister Leposava. The process of magical healing that Leposava conducts develops through several stages: the first includes contact with the supernatural, judging by what the interlocutor shares, through a sort of ritualistic trance ("And she conversed and sang, with the fairies, with the angels, with Jesus Christ and all, and he said..." [4]). Next came the ritual of pouring molten lead, which identifies the person who caused the problem (having had paid to cause trouble to the interlocutor and her spouse); the sick couple then spent a few days in the healer's house, being fed only a little wine that had previously been sanctified in a church (reminiscent of the Eucharist), and were 
ritually washed several times in a river water in which herbs were submerged (a type of purification where one counts on the magical power of herbs). At the close of this period, the healer sends the couple to participate in a ritual that marks the church's slava ${ }^{21}$ where the gifting of votive objects can be interpreted as a payment to the metaphysical entity for a successful healing. The description of the healing process ends with the assertion that there should be a two-month ban from public spaces.

The story's dynamic is achieved though frequent scene changes, a number of actors, the narration of the dialogue segments that are each introduced, as well as the descriptions of the emotional experiences and reactions of the narrator and other actors. The narrative skills of the interlocutor are also reflected in her character development. Apart from direct characterisation through narrative comments, dialogue segments allow the characters' voices to be introduced into the narrative (even in scenes where the interlocutor herself hadn't been present and where indirect experience and knowledge is central), and this technique allows for personal drama and a convincing portrayal of events.

Considering the extent and diversity of the narrative strategies and the colourful nature of the author's (metatextual) comments, this story offers multiple messages: as well as suggesting the actions that should be taken when a problem appears (from the perspective of a belief system that functions in the framework of traditional culture) and the assessment of the effectiveness of magical healing, it also speaks of the sanctions that are to be endured by one who reaches for black magic (in the digression on the fate of the person who caused the harm: "Maybe you know Dripalka, Stevka, Jevrosima's granddaughter. She's a hermit, all alone, God gave up on her, she even ruined another house..." [4]). Throughout the story of the healing process, an idea about the different bearers of magical knowledge develops, their domains of competence, and the type of "network" they form. The concept of the cunning woman Leposava is built, among other ways, through an explicit assessment of her competence ("She is God's cunning woman") and the breadth of her activities through a spectrum of clients ("She even went to Belgrade to heal, she healed professors..." [4]). A short digression on the punishment that catches up with the healer for refusing to heal a little girl illustrates the system of rules that the bearers of magical knowledge are subject to ("Eh, I'll tell you about that after, God punished her afterwards because she wouldn't heal this one child..." [4]). The interlocutor later went back to this motif and developed it in the conversation, and also spoke of how the cunning woman Leposava acquired her magical knowledge (the Virgin Mary appeared to her in a dream). Meanwhile, due to the length of this text, I have abbreviated these narrations, I highlight these points to clarify the process of the formation of a cluster of narratives around a specific healer.

Elements of the "ideal model" described are therefore recognised even in stories related from the perspective of the patient, but the storyteller as an actor is in an entirely different position. The position of the patient, the one who is in need of help, creates conditions in which the account of the effectiveness of magical practice is focused on a personal experience of illness and the process of magical healing, the emotional and physical states. Even in this type of narrative, descriptions of magical practice are left in the background (this time seen from the "outsider" perspective), but it may include data on

${ }^{21}$ Celebration of church patron saint's day. 
the magical actions prescribed for the patient to undertake. These actions are prescribed by the bearer of magical knowledge, and in that relation, the patient as an actor is in a subordinate position. This passive position is especially recognised in example [4]: the influence of the sick couple on the development of the events is minimised, the initiators of action are the authority figures (grandfather Žika, whose position is additionally determined by the fact that he was the head of the family), or those whose position is based on their knowledge of magical practices (the cunning folk). The passive position of the patients in the interlocutor's memory is also explained, and the unreliability of memory ("And afterwards we went to the St. Lazar church on foot. We didn't even feel it. Maybe we took a drive there, I don't know. Grandma sat up front, we were behind her..." [4]) can, beside temporal distance, be analysed through the specific emotional state of the patients (worry, fear, pain). From another perspective, the patient as the protagonist - witness of events - and storyteller (when the communicative situation of storytelling is concerned) performs from a position of authority. Still, this position is actually realised through the hybridising of several planes, bearing in mind the impossibility of equating the narrator and the projected " $\mathrm{I}$ " in the text already mentioned (which presumes a further reconceptualising of events in line with the demands of the communicative situation). Distance over time and post festum interpretations of the experience open up a way to interpret the specific event on the basis of later relationships (e.g., connecting the blast of the wind to the illness [3], linking the first symptoms of illness to meeting a concrete person [4]). The formation of these links is based on a system of belief and collective concepts that function in traditional culture.

The means of establishing causal relationships between events, the storytelling techniques which have been considered, the form of the memorate (or memorato-fabulate), the positioning of the actors, the ways narratives fit into the complex of ideas and norms that function in a specific community, the paralinguistic elements, are all characteristic elements of the rhetoric of truth, even in these types of stories. The main differences between stories that are shaped by cunning folk and those told from the perspective of the patients are particularly registered in the evaluative plane of the narrative. Instead of the "rhetoric of competence" (as a dominant framework where cunning folk's stories of their own practice belong), the evaluations and comments of the narrator (who takes the role of the patient) - and with that the point of the narrative - can be linked to different aspects of the recounted content. This fact highlights that the experience the individual went through was unusual (while fitting it into the broader context of his/her life history), sharing the attitude towards traditional medicine and magic (which can often include a before/nowadays opposition), the theme of the relationship with the supernatural and transcendental, virtue and sin, the system of taboos, etc. In a realistic communication situation, these stories can have a heightened didactic and advisory function (when, by sharing personal experience, one is urged to seek magical healing), and can also function as elements of a wider spectrum of narration that are shaped in relation to the specific healer. Complementary to that, stories shaped from the cunning folk's perspective may also, explicitly or implicitly, include semantically similar layers, and thus the typological differences in an evaluation plane between narrations shaped from the two perspectives considered should be discussed as a tendency rather than as a generally valid principle. 


\section{The "life" of the story}

Observing stories about magical healing as a folklore genre allows for not only stability of the motifs but also for the possibility of further transmission. Indeed, some of them are known not only to the healer and patient but also to other members of the community, with the possibility of ever wider transmission. It seems that the "life" of a story is most often assured by the fact that it is tied to particularly prominent individuals (cunning folk), or the stories develop into elements of family folklore ([4]). At the same time, through everyday communication, stories like these can become part of the knowledge of cousins, friends, neighbours, and those who have developed a taste for magical healing. The "life" of the story needn't be limited to the survival of the same narrative with the same actors - it also relates to the constancy of the model and belief system and the ideas that model generates. Even though this study is primarily focused on the function of stories in oral communication within the framework of local communities, it is impossible to overlook the role of written and electronic media in a modern framework when it comes to transmitting narratives linked to different aspects and types of healing practices (RAdulović, L. 2000; Trifunović 2012). And thus, healing stories are linked to, among others, music stars, politicians, reality show participants. What follows is part of an interview with an interlocutor from Vlahovo (southeastern Serbia) that illustrates two processes: the transmission of a personal experience story through oral communication, and the transmission of a healing story of a music star, which the interlocutor adopted from the television. The type of healing in the second story was not specified (later in the interview, it was mentioned that the healer attained her psychic vision after a near-death experience, being proclaimed clinically dead), but the link to traditional magic points to the interlocutor's experience that all types of healing practices are similar. While forming the rhetoric of truth, the fact that the story made its way into the media undoubtedly played an important role (and thus the interlocutor expected that I had heard of it, too). The interlocutor's attention was undoubtedly drawn by the fact that the music star who had been healed originally came from the same area as her, a nearby village.

\section{[5]}

[the interlocutor speaks of various family and personal health problems]

“And we went [to the cunning man], and he said: - You've been attacked, he says, by a voden živak. ${ }^{22}$ - And I felt much better after he charmed. He charmed at the water. (...) [the cunning man told her]: - And at night you drink the water and you'll feel better. You'll either have diarrhoea, or you'll be throwing up, you're going to feel, he says, small... [the patient took the advice] When I got up in the morning, son, and I went into the street, and I felt light, you know light, easy, and it seemed like I could fly. I felt like flying. One woman said from above: - Senžana, what are you doing? - I said: - Nothing, it's making me fly, I said. - And she says: - Why? - I said: - I went to see Milenko yesterday and he, I said, conjured the water and I drank, I said, and I drank it last night, drank it until the morning, and now I'm, I said, light, it's making me fly...

[next are several stories about the cunning man Milenko]

22 Živak is a demonic being that is magically set upon a person in order to inflict harm (illness, death), RADENKOVIĆ 1982:391. 
Over there was some woman, she says, over there. She had a television. Nemanja the singer took someone (...) from Parovi, ${ }^{23}$ I don't know what the name of that girl from Niš was. And she also went to that cunning woman, said: - Who drove you over? - Well, she says, Nemanja drove me. - Go and call him so I can cure his back problems. - She knew it was Nemanja, and knew it was a red car, and she hadn't seen it, but it moved her, she had seen a foretelling. And he went in, and she charmed, and now his back doesn't hurt. It was on television. (...) It all exists. There is God's power for everyone..."

\section{Cumulativity}

Tying and linking healing stories in oral communication, especially expressed in the narratives of cunning folk, leads to the formation of narrative macro-blocks, which is to be expected up to a point as it is related to narratives that have a fundamental role in the formation of the "rhetoric of competence". The same principle can also function in conversations about traditional medicine and magic generally, not only in a folkloristic interview but particularly in everyday communication. The cumulativity is therefore seen as the fruit of the "logic" of how each storytelling situation functions, whereby narratives similar in theme and genre are linked by association.

\section{TOWARDS A CONCLUSION: STORIES OF MAGICAL HEALING AS PART OF "EVERYDAY MYTHOLOGY"}

The distinctive features of the stories of magical healing discussed above - thematic (meeting of the natural and supernatural as the core of the narrative), structural (stability of motifs, incorporation of other folklore genres - curses, blessings, didactic statements, cumulativity), and ideological (being based on a system of beliefs) - make it possible for these narratives to be also viewed as the modes of realisation of a mythological text, since the mythological text, as demonstrated by the author of this concept, Elena Levskievskaia (LEVSKIEVSKAIA 2006), is realised as a syncretic narrative in a realistic conversation situation. ${ }^{24}$

23 This is a TV reality show (a format similar to Big Brother) that was very popular at the time this conversation was recorded.

24 A "mythological text" is considered to be a text from a traditional culture containing information on demonic phenomena (in different manifestations) that are interpreted as elements of reality, and the mythological information is realised through semantic models ingrained in the memory and culture of a community. It relates to a speech genre text that is realised through a spectrum of genres (legend, expressing beliefs, didactic statement, magical text focused on communication with the supernatural), and it functions in everyday communication, in ritual and semi-ritual situations. The choice of genres, their combination and pragmatics are conditioned by the type of speech situation, the ratio and distribution of power and authority between the participants in the communication, and the intentions of the storyteller (LeVSKIEVSKAIA 2006:150-151). The study of the communicative characteristics of mythological texts is further developed by Viktoriia Chervaneva, and the role of individual experience in the interpretation of content is specially examined in her study on the subgenre of personal interpretation (CHERVANEVA 2017). For the personal interpretation of collective practice in autobiographical narratives, see also Petrović 2008. 
The role of context in the formation and reception of legends has been illuminated from various angles, and that context is seen from the broadest socio-cultural environment and belief systems that function within it (DÉGH 2001), right up to the micro-context of the specific communication situation. Summing up the research results of the (oral) narrative context, Ülo Valk points out: Some verbal genres can easily be distinguished from the flow of communication, as stylistic or performative features mark them off, but there is also a range of verbal genres that are "not rendered as performances". Legend as a distinct communicative genre often remains indiscernible, because it is "not set apart from the flow of conversation through the use of distancing formulas" (VALK 2015:141).

Although healing stories in a folkloristic interview are contextualised through the partially structured dialogue between the researcher and the interlocutor, in everyday communication situations, they can easily turn into a conversational whirlwind. And thus they become everyday, common stories in the community. It must be pointed out, however, that even though a type of narrative can be recognised as an element of everyday conversation, it does not automatically mean that it is about narrating the mundane (secular) experience.

Still, it would seem that in the folklore genre system, stories of magical healing occupy a liminal space, right at the crossroads of two semantic fields, the demonologically coded and the secular(ised), as the connection with the supernatural is sometimes only latently present. Gravitation towards one or another spectrum of meaning is determined by a series of factors. The tendency to secularise is achieved through narrative techniques (for example, introducing a larger number of everyday scenes, leaving out anything explicit in regards to the demonic sphere, forming a point that is oriented to the secular plane, assessing the morality of someone's actions, the story as part of the picture of elements of traditional culture, etc.), but also through paralinguistic elements (a storyteller's way of experiencing narrative content that is "read" from the way the story is told and the way the atmosphere of the story is shaped - volume or tone of voice, pauses or lack thereof, delivering content without hesitation, etc.). The impression of the secularisation of the story depends on the concrete narrative environment. For example, the magical healing story in example [3] was introduced into the conversation by being linked to previous demonic content (talking about fairies), and therefore we can see the demonic connotations from the start. The position of the story from example [4] is somewhat different, as it enters the healing story through an autobiographical narrative (memories of the wedding), and the demonic coding is introduced gradually through both direct and indirect signals. We can, therefore, speak of a semantic inertia in the context (ĐorĐević BeLIĆ 2013:240-242) that affects the experience, reception, and interpretation of the story content. Viewed from a reverse perspective, stories of magical healing introduce mythological-demonological elements into the everyday, and they make abstract demonic content concrete by linking it to the plane of experience.

As previously asserted, stories of magical healing are personal experience stories (whether they concern direct - personal - or indirect - someone else's - experience). Even though personal experience stories are often implicitly viewed as narratives about content related to a secular framework and the mundane (often connoted by the terms "telling about life", "stories from life", "talking from life"; for the analysis of these and 
similar terms $\mathrm{s}^{25}$ ), the field of personal experience stories partially overlaps with genres that are similar to legend. Thus, Dolby Stahl (STAHL 1989) distinguishes three forms of personal narratives: apart from "life history" as the most developed, multiple-episode narrative, she also recognizes narratives that the narrator and listener experience as being linked to the supernatural (memorate), and ones they view as being linked to secular experience. The key remark Dolby Stahl makes concerns the differences in subgenres that are based on individual experience and assessment. Therefore, the tendencies related to secularisation are linked to a specific cultural context. In this way so we must count on the possibility of differentiating the experience of narrative content in an emic and etic perspective. Hypothetically speaking, if magical healing in a specific community (or among the participants of a specific communication situation) is part of usual behaviour, then stories of such healing become closer to stories about everyday experience (whereas the researcher may experience such stories as something quite unusual; for the illustration of how this functions in everyday conversation, see example [5]). ${ }^{26}$ The cunning folk's stories are stories concerning elements of their everyday life because the link with the metaphysical is part of their identity. It is understood that stories of magical healing are never completely free of connotations related to the supernatural, even if the degree of demonological coding is reduced because of context or by using the above-described narrative strategies. After all, the question of experience and the nature of contact with the otherworldly is individually conditioned.

The mythological-demonological experience in the stories of magical healing is always in relation to social experience, and thus these stories may be viewed as "the mythology of everyday life". ${ }^{27}$

The change of perspective opens up the question of the social function of magical healing stories. Viewed theoretically, the practice of charming manifests itself on

25 (ras)skaz, memorabile; see BošKović STULli 1988:15-22.

26 Even though Vladimir Bahna's study focused on what the frequency of circulation depends on and the creation of so-called false memories from cultural context, one of his observations is worth mentioning: "I found that in the surroundings of those individuals who reported an experience with a supernatural agent, other similar stories were in circulation, telling of similar experiences by a person socially relevant to these individuals: close relatives, best friends, important family friends, and persons seen as authoritative on the basis of institutionalised office or professional expertise. Moreover, these memorates were supported within the immediate community by a positive stance toward the experience, frequent occasions of collective remembering, or by mutually supporting testimonies of individuals with similar experiences. On the other hand, in those parts of the local society where personal experiences of this kind did not occur, the knowledge of traditional narratives and beliefs was fragmentary, and on the edge of social interest, mostly triggering a negative attitude among the local majority and influential individuals. These findings support the hypothesis that memorates are more frequent where the source of the tradition is associated with the kind of social contexts which have been seen in experimental research as increasing the probability of false memories formation" (BAHNA 2015:15).

27 Aleksandr Panchenko (2002) suggests that it is linked to dream stories; stories of magical healing are also viewed as an expression of the vernacular religion in everyday life (KIs-HaLAs 2012). A sort of "magical match" to healing stories would be verbal charms, the subject of which is based on the description of the process of magical healing: the patient meets the Virgin Mary (or a healer), tells her the "history of the disease"; the Virgin Mary sends the patient to the healer, who then uses magical acts to stave off the disease. Yet, reciting an incantation is linked to ritual (communication of the healer with the supernatural entity), while healing stories are formed in mundane conditions of conversation. 
two planes: the "real" (the very act of performing the ritual), which is in the sense of "external" perception quite limited, relatively hidden, and the narrative, which is shaped around practice. If, as Mina Velčić puts it (Velčŕć 1989b), we all live our lives through the form of narrative experience, it is true that "narrative manifestation" (Hesz 2007:20) is essential for the survival of the practice, especially as the narrative becomes the means through which practices from the domain of the obscure stream into the non-private, public, accessible sphere. In the context of charming tradition, the competence of the bearer of the practice represents a complex category formed by crisscrossing multiple perspectives. The "external" includes a spectrum of attitudes based on the perceptions of the (narrower or wider) community members (recognizing, marking, assessing), while the "internal" is created from the angle of the very bearer of the tradition.

Those who possess (socially verified) knowledge and skills from the domain of traditional medicine are, as a rule, noted individuals in the community. Their status secures the narrative formed around the concrete repertoire, with accent of magical knowledge, the assessment of the effectiveness of its application (including ideas on the breadth and characteristics of their social network of "clients"), and around the individual views of all the actors. Founded in the belief that it is possible to direct and manipulate reality, magical practice is marked with a potential possibility of a double (positive and negative) outcome. Seen from this angle, a practitioner of magical healing can be viewed as a "distanced other", desired yet dangerous, "chosen" yet "impure" (Todorova-Pirgova 2003:49), and thus the relationship towards him/her includes a dose of respect, but also a dose of fear (MencEJ 2006:219-221). The ambivalence in the reception of magical practices (on the level of good/evil, positive/negative, black/white magic), with reference to their bearers (including the possibility of overlapping different domains of action, and therefore contact with the metaphysical entity having positive or negative connotation), is recognised as a cultural constant. ${ }^{28}$

Stories told by cunning folk about successful magical healing are, therefore, important factors in their social positioning and verification of magical practice. The circulation of the narratives about magical healing within the framework of a community contributes to creating a picture of the specific bearers of the practice, the domain of their competences, and the effectiveness of their ritual acts. Viewed more broadly, it also creates ideas about natural and supernatural, worldly and otherworldly, eschatology, morality, and codes of conduct in the broadest sense. And when it comes to these narratives, we cannot exclude the potential propaganda function, either.

Still, as they are based on belief in the supernatural cause of illness, the interpretation of magical healing stories may have another prognostication: they can express scepticism or a complete rejection of belief in the effectiveness of this manner of healing. In these frameworks, even the bearers of magical practice would be marked negatively, and the indulgence of magical healing would be attributed to a series of "others" (for example, individuals assessed to be low on the social ladder, cheats, those belonging to other ethnic groups, etc.). Yet, there is no doubt that these healing stories contribute to shaping the concepts of tradition, even when that tradition is rationalised, subjected to doubt, or disagreed with.

${ }_{28}$ See examples from different traditions described in MenCes 2006:220. 


\section{REFERENCES CITED}

Agapkina, Tatiana

1999 Zagovory. Slavianskie drevnosti. Enciklopedicheskii slovar' [Incantations. Slavic Antiquities. Encyclopedic Dictionary]. Tom II., 239-244. Moskva: Rossiiskaia Akademiia nauk: Institut slavianovedeniia.

2003 Poleskie zagovory. Principy nauchnogo izdaniia [Incantations of Polesie. Principles of Scientific Publication]. In Agapkina, Tatiana et al. (eds.) Poleskie zagovory (v zapisiakh 1970-1990-kh gg.), 7-20. Moskva: Indrik.

Agapkina, Tatiana et al. (eds.)

2003 Poleskie zagovory (v zapisiakh 1970-1990-kh gg.) [Incantations from Polesie (Records from the Years 1970-1990)]. Moskva: Indrik.

AJDAČı́́, Dejan

1995 Religija i priče o isceljivanju [Religion and Healing Stories]. Književna reč 23(459)IV.

AnIKIn, Vladimir P. (ed.)

1998 Russkie zagovory izaklinaniia. Materialy fol'klornykh ekspedicii Moskovskogo gosudarstvennogo universiteta 1953-1993 gg. [Russian Incantations and Spells. Materials of the Folklore Expedition of the Moscow State University 1953-1993]. Moskva: Izdatel'stvo Moskovskogo universiteta.

BAHNA, Vladimir

2015 Memorates and Memory: A Re-evaluation of Lauri Honko's Theory. Temenos 51(1):7-23.

BENNETT, Gillian

1985 Heavenly Protection and Family Unity: The Concept of the Revenant among Elderly Urban Women. Folklore 96:87-97.

BENOvSKA-SĂBKova, Milena

1994 Extra-Sensers: The Magicians of the New Time. In AJdAčić, Dejan (ed.) The Magical and Aesthetic in the Foklore of Balkan Slavs, 141-156. Belgrade: Library "Vuk Karadžić".

BoATright, Mody C.

1958 The Family Saga as a Form of Folklore. The Family Saga and Other Phases of American Folklore, 1-19. Urbana: University of Illinois Press.

BošKović STUlLI, Maja

1975 Narodna predaja - Volkssage - kamen spoticanja u podjeli vrsta usmene proze [Folk Legend - Volkssage - Stumbling Stone in Classifying the Types of Oral Prose]. In BošKović Stulli, Maja (ed.) Usmena književnost kao umjetnost riječi, 121-136. Zagreb: Mladost.

1988 Telling about Life (On Questions of Contemporary Oral Literary Genres). Narodna umjetnost. Special Issue (2):11-42.

Chervaneva, Viktoriia

2017 Rechevye zhanry mifologicheskogo teksta: subzhanr lichnoi interpretacii [Speech Genres of a Mythological Text: a Subgenre of Personal Interpretation]. Vestnik VGU 1:76-78. 
ĆIRKović, Svetlana

2006 Linguistic Anthropology of Enclaves: Possibilities of Transcript Analysis. Symposia. Journal for Studies in Ethnology and Anthropology 331-348.

2015 Upotreba citata u usmenim narativima o tradicionalnoj medicini u Ibarskom Kolašinu: od istinitosti do evidencijalnosti [The Use of Quotations in Oral Narratives of Traditional Medicine in Ibarski Kolašin: From Truthfulness to Evidentiality]. In Polomac, Vladimir - KovačEvić, Miloš (eds.) Putevima

DÉGH, Linda srpskih idioma, 207-229. Kragujevac: FILUM.

1995 Narratives in Society: A Performer-Centered Study of Narration. Helsinki: Academia Scientarum Fennica.

2001 Legend and Belief. Dialectics of a Folklore Genre. Bloomington: Indiana University Press.

DeLIĆ, Lidija

2018 Usmena predanja: Now you see me! [Folk legends: Now you see me!]. In Milosavljević, Snežana et al. (eds.) Od narativa do narativnosti. From Narrative to Narrativity, 141-150. Niš: Filozofski fakultet.

Dolby STAHL, Sandra

1989 Literary Folkloristics and the Personal Narrative. Bloomington: Indiana University Press.

ĐorĐević, Smiljana

2008 Magijski tekst bajanja: između verbalnog tabua i folklorizma [The Magical Text of Charms: Between Verbal Taboo and Folklorism]. In LJubinković, Nenad - SamardžJua, Snežana (eds.) Srpsko usmeno stvaralaštvo, 389-429. Beograd: Institut za književnost i umetnost.

2011 Priče o (uspešnim) izlečenjima: okviri govornog žanra [Stories of Successful Healing: Frames of Speech Genre]. In Detelić, Mirjana - SAmardžIJA, Snežana (eds.) Živa reč: zbornik u čast prof. dr Nade Milošević-Đorđević, 165-189. Beograd: Balkanološki institut SANU, Filološki fakultet.

ĐorĐević Belić, Smiljana

2013 Savremena terenska istraživanja tradicijske kulture - demonološko predanje [Contemporary Field Research of Traditional Culture: Demonological Legend]. In Karanović, Zoja - JoKić, Jasmina (eds.) Savremena srpska folkloristika 1., 233-250. Novi Sad: Filozofski fakultet.

2015 Istraživač, pacijent, kradljivac: terensko dokumentovanje bajanja iz domena tradicionalne medicine [Researcher, Patient, Thief: Field Documentation of Charms in the Domain of Traditional Medicine]. In ĐorĐEvić, Smiljana et al. (eds.) Savremena srpska folkloristika 2., 415-443. Beograd: Udruženje folklorista Srbije, Institut za književnost i umetnost, Univerzitetska biblioteka "Svetozar Marković".

HedeşAn, Otilia

2003 Myth and/or Shamanism. Case Analysis: Pauna of Trešnjevica. In ĐorĐević, Dragoljub (ed.) Roma Religious Culture, 84-93. Niš: Yugoslav Society for the Scientific Study of Religion. 
2005 Jedan teren - Trešnjevica u dolini Morave [A Field: Trešnjevica, in the Morava Valley]. In SiKıмıć, Biljana (ed.) Banjaši na Balkanu. Identitet etničke zajednice, 13-106. Beograd: Balkanološki institut Srpska Akademija Nauka i

Hesz, Ágnes Umetnosti.

2007 The Making of a Bewitchment Narrative. Folklore. Electronic Journal of Folklore 37:19-33.

Honko, Lauri

1964 Memorates and the Study of Folk Beliefs. Journal of the Folklore Institute 1(1-2):5-19.

ILIĆ, Marija

2007 A Shift in Ethics. The Serb/Albanian Conflict in the Vernacular Discourse of a Conjurer from Kosovo. Zeitschrift für Balkanologie 43(2):145-167.

Kis-Halas, Judit

2012 “I Make My Saints Work...”: A Hungarian Holy Healer's Identity Reflected in Autobiographical Stories and Folk Narratives. In Bowman, Marion - VALK, Ülo (eds.) Vernacular Religion in Everyday Life, 63-92. London: Routledge.

KLIAus, Vladimir L.

1998: Shto takoe zagovor? (K probleme zhanrovoi differenciacii zaklinatel'nogo fol'klora) [What is an incantation? [On the Problem of Genre Differentiation in the Folklore of Verbal Charms]. Tezisy konferencii "Slovo kak deistvie", 37-42. Moskva: "Dialog-MGU".

LABOV, William

1972 Language in the Inner City: Studies in the Black English Vernacular. Philadelphia: The University of Pennsylvania Press.

LABOV, William - WALETZKY, Joshua

1967 Narrative Analysis: Oral Versions of Personal Experience. In Helm, June (ed.) Essays on the Verbal and Visual Arts, 12-44. Seattle: University of Washington Press.

LEVKIEVSKAIA, Elena E.

1999 Znahar'. Slavianskie drevnosti. Enciklopedicheskii slovar' [Healer. Slavic Antiquities. Encyclopedic Dictionary]. Tom II., 347-350. Moskva: Rossiiskaia Akademiia nauk: Institut slavianovedeniia.

2006 Pragmatika mifologicheskogo teksta [The Pragmatics of a Mythological Text]. Slavianskii i balkanskii fol'klor. Semantika i pragmatika teksta 10:150-213.

Menceu, Mirjam

2006 "Ja, tam je en takšen, ko zna". Vedeževalci - nasprotniki čarovnic na slovenskem podeželju ["Yeah, There's Someone who Knows". Soothsayers as Anti-Witches in Rural Slovenia]. Studia Mythologica Slavica 9:203-222.

MILOŠEVIĆ ĐORĐEVIĆ, Nada

2006 Od bajke do izreke [From Fairy Tale to Saying]. Beograd: Društvo za srpski jezik i književnost.

Mitseva, Evgenia

1994 Old-time Wizards and Present-day Extra Senses. In AJDAČIć, Dejan (ed.) The Magical and Aesthetic in the Folklore of Balkan Slavs, 157-163. Belgrade: Library Vuk Karadžić. 
Moroz, Andrei (ed.)

2012 Znatki, veduny i chernoknizhniki: koldovstvo i bytovaia magiia na Russkom Severe [Enchanters, Wizards, and Warlocks: Witchcraft and Household Magic in the Russian North]. Moskva: FORUM, Neolit.

OrING, Elliott

2008 Legendry and the Rhetoric of Truth. Journal of American Folklore 121(480):127-166.

PANChenko, Aleksandr A.

2002 Son i snovidenie v traditsionnykh religioznykh praktikakh [Sleep and Dream in Traditional Religious Practices]. In Hristoforova, Olga (ed.) Sny i videniia $v$ narodnoi kul'ture. Mifologicheskii, religiozno-misticheskii i kul'turnopsikhologicheskii aspekty, 9-25. Moskva: Rossiiskii Gosudarstvennyi Gumanitarnyi Univ., Inst. Vyschikh Gumanitarnykh Issledovanii.

PEŠIKAN-LJUŠTANOVIĆ, Ljiljana

1992 Čudesno izlečenje kao tema urbanog predanja [Miraculous Healing as a Theme of Urban Legends]. Folklor u Vojvodini 6:94-102.

Petrović, Sonja

2008 Priča i sećanje: neki primeri autobiografskog diskursa u folklornim terenskim zapisima iz Srbije [Narrative and Memory: Some Examples ofAutobiographical Discourse in Folklore Field Recordings in Serbia]. Književnost $i$ jezik $\operatorname{LV}(3 / 4): 339-354$.

Plotnikova, Anna A.

2004 Etnolingvisticheskaia geografiia iuzhnoi slavii [The Ethnolinguistic Geography of Southern Slavs]. Moskva: Indrik.

Popović, Danijela

2014 "Al' ovo nije bajka nego istinito": Diskurs vernosti u demonološkim predanjima ["This Isn't a Fairy Tale, but True". A Discourse of Authenticity in Demonological Legends]. In ĐorĐević BeLIĆ, Smiljana et. al. (eds.) Savremena srpska folkloristika 2., 229-243. Beograd: Udruženje folklorista Srbije, Institut za književnost i umetnost, Univerzitetska biblioteka "Svetozar Marković".

Publichuk, E. V. - Toporkov, Andrei

2012 "Gde-to chto-to est"”: znaharka iz Andomy o zhizni, o vere i ob opyte celitel'stva [Somewhere There is Something: A Healer from Andoma on Life, Faith, and the Experience of Healing]. In Smilianskaia, E. B. (ed.) O svoei zemle, svoei vere, nastoiashem i perezhitom v Rossii XX-XXI vv. (k izucheniiu biograficheskogo i religioznogo narrativa), 235-260. Moskva: Indrik.

RADENKović, Ljubinko

1982 Narodne basme i bajanja [Folk Incantations and Verbal Charms]. Beograd: Balkanološki institut Srpska Akademija Nauka i Umetnosti.

1996 Narodna bajanja kod Južnih Slovena [South Slavic Folk Incantations]. Beograd: Balkanološki institut Srpska Akademija Nauka i Umetnosti.

RADUlOVIĆ, Lidija

2000 Čudna nam čuda: Savremeni folklor paranormalnog [Strange Miracles: Contemporary Folklore of the Paranormal]. In AJdAČIĆ, Dejan (ed.) Čudo u slovenskim kulturama, 364-380. Beograd - Novi Sad: Naučno društvo za slovenske umetnosti i kulture - Apis. 
RAdulović, Nemanja

2018 Contemporary Magic Healing in Serbia and New Age. In Radulović, Nemanja - Hess, Karolina Maria (eds.) Studies on Western Esotericism in Central and Eastern Europe. Szeged: JATE Press.

ROPER, Jonathan

2003 Towards a Poetics, Rhetorics and Proxemics of Verbal Charms. Folklore. Electronic Journal of Folklore 24:7-49.

Ross, Bruce M.

1992 Remembering the Personal Past: Descriptions of Autobiographical Memory. New York: Oxford University Press.

RudAN, Evelina

2006 Authentication Formulae in Demonological Legends. Narodna umjetnost 43(1):89-111.

SAMARDŽIJA, Snežana

2011 Oblici usmene proze [Genres of Oral Prose]. Beograd: Službeni glasnik.

STARK, Laura

2009 The Charmer's Body and Behaviour as a Window onto Early Modern Selfhood. In Roper, Jonathan (ed.) Charms, Charmers and Charming. International Research on Verbal Magic, 3-16. London - New York: Palgrave Macmillan.

Todorova-PIrgova, Iveta

2003 Baianiia i magii [Verbal Charms and Magic]. Sofia: Akademichni izdatelstvo "Prof. Marin Drinov".

Trifunović, Vesna

2012 Moć narativa: uticaj priča o izlečenju putem nekonvencionalne medicine [The Power of Narrative: The Impact of Stories about Healing through Unconventional Medicine]. Etnoantropološki problemi 7(4):979-998.

USACHEVA, Valeria V.

2000 Kontakty cheloveka s demonami boleznei: sposoby zaschtchity i izbavleniia ot nikh [Human Contacts with Demons of Diseases: Ways to Protect and Get Rid of Them]. In Sofronova, L. A. - Titova, L. N. (eds.) Mif v kul'ture: chelovek - ne-chelovek, 56-74. Moskva: Indrik.

VALK, Ülo

2015 Discursive Shifts in Legends from Demonization to Fictionalization. Narrative Culture 2(1):141-145.

2016 The Quest for Meaning in Folklore and Belief Narrative Studies (with Special Reference to Assam). In Khiangte, Zothanchhingi (ed.) Orality: the Quest for Meaning, 22-37. Partridge Publishing India.

VELČIĆ, Mirna

1989a Što je (auto)biografski diskurs? [What Is an (Auto)Biographical Discourse?]. Quorum V/3(26):15-32.

1989 b Personal Narrative as a Research Method in Folklore. Narodna umjetnost 26:81-89.

Velmezova, Ekaterina V. (ed.)

2004 Cheskie zagovory [Czech Incantations]. Moskva: Indrik.

WiLson, William A.

1991 Personal Narratives: The Family Novel. Western Folklore 50(1):127-149. 
Zeitlin, Steven J.

1980 An Alchemy of Mind: The Family Courtship Story. Western Folklore 39:17-33.

Smiljana Đorđević Belić is a Senior Research Associate at the Institute for Literature and Arts, Belgrade. Her research interests are focused on oral epics, belief narratives and traditional magic. Her publications include: Postfolklorna epska hronika. Žanr na granici i granice žanra [The post-folk epic chronicle: A genre on the border and the borders of the genre]. Belgrade: Institute for Literature and Arts, 2016; Figura guslara: heroizirana biografija i nevidljiva tradicija [The figure of the gusle player: A heroicized biography and an invisible tradition], Belgrade: Institute for Literature and Arts, 2017; "Formula in transformation: Harbinger Fairy". In Epic Formula. A Balkan Perspective. Edited by Lidija Delić and Mirjana Detelić. Belgrade: Institute for Balkan Studies, 2015, 201-212; "The Motif of Extinguishing Fire With Grass and Water in One Type of Serbian and South Slavic Chanting". In Plants and herbs in traditional Serb Culture. Edited by Zoja Karanović. Belgrade: University Library "Svetozar Marković", 2016, 69-83. E-mail: smiljana78@yahoo.com

Open Access. This is an open-access article distributed under the terms of the Creative Commons Attribution-NonCommercial 4.0 International License (https://creativecommons.org/licenses/by$\mathrm{nc} / 4.0 /$ ), which permits unrestricted use, distribution, and reproduction in any medium for noncommercial purposes, provided the original author and source are credited, a link to the CC License is provided, and changes - if any - are indicated. 